\title{
The influence of BMI and psychological variables in the body size estimation among adult women
}

\author{
Gabriela Salim Xavier \\ Sebastião Sousa Almeida \\ Universidade de São Paulo, SP, Brasil
}

\begin{abstract}
This study aimed to quantify the body size estimation to evaluate the variables that influence it - Body Mass Index (BMI), body image dissatisfaction and depressive symptoms in normal $(\mathrm{N}=40)$ and overweight women $(\mathrm{N}=40)$. The body image and depressive symptoms assessment were conducted by the Brazilian Figure Rating Scale (FRS) and the Beck Depression Inventory (BDI) in its Brazilian versions, respectively. In the Normal weight group, the dissatisfaction and BDI scores explained $55 \%$ and $12 \%$ of the estimation variance, respectively. In the Overweight group, the body image dissatisfaction accounted for $14 \%$ of the variance of body size estimation while the BMI individually made in only $9 \%$. When evaluated together, this percentage increased to $42 \%$, indicating that together - BMI and dissatisfaction - aggregate greater explanatory value to this variation. The dissatisfaction was considered the most salient variable, which has influenced large percentages in the estimation values obtained, particularly among normal weight women.
\end{abstract}

Keywords: Body image; Body Size Estimation; Women; Body Mass Index; Satisfaction.

\section{A influência do IMC e variáveis psicológicas na estimação da imagem corporal em mulheres adultas}

\section{Resumo}

O objetivo desse estudo foi quantificar a estimação da imagem corporal para avaliar as variáveis que a influenciam - Índice de Massa Corporal (IMC), insatisfação com a imagem corporal e sintomas depressivos em mulheres eutróficas ( $n=40)$ e com excesso de peso $(n=40)$. A avaliação da imagem corporal e dos sintomas depressivos foi conduzida por meio da Escala de Figuras de Silhuetas (EFS) e pelo Inventário de Depressão de Beck (BDI), em suas versões brasileiras, respectivamente. No grupo eutrófico, a insatisfação e a pontuação do BDI explicaram 55\% e 12\% da variação da estimação, respectivamente. No grupo com excesso de peso, a insatisfação com a imagem corporal foi responsável por 14\% da variação da estimação da imagem corporal, enquanto o IMC, individualmente, por somente $9 \%$. Quando avaliados em conjunto, esse percentual aumenta para $42 \%$, indicando que juntos - IMC e insatisfação - agregam maior valor explicativo para essa variável. A insatisfação foi considerada a variável mais saliente, influenciando em maiores proporções os valores de estimação obtidos, particularmente entre as mulheres eutróficas.

Palavras-chave: Imagem Corporal; Estimação; Mulheres; Índice de Massa Corporal; Satisfação.

\section{La influencia de IMC y variables psicológicas en la estimación del tamaño corporal entre las mujeres adultas}

\section{Resumen}

El objetivo de este estudio fue cuantificar la estimación del tamaño corporal para evaluar las variables que influyen - Índice de Masa Corporal (IMC), la insatisfacción de la imagen corporal y los síntomas depresivos en mujeres com peso normal ( $\mathrm{n}=40$ ) y con sobrepeso $(\mathrm{n}=40)$. La evaluación de la imagen corporal y los síntomas depresivos fueron realizados por la Escala de las figuras de silhuetes (EFS) y el Inventario de Depresión de Beck (BDI) en sus versiones brasileñas, respectivamente. En el grupo de peso normal, la insatisfacción y las puntuaciones del BDI explican 55\% y 12\% de la varianza de estimación, respectivamente. En el grupo con sobrepeso, la insatisfacción con la imagen corporal representó el 14\% de la varianza de la estimación del tamaño del cuerpo, mientras que el IMC hecha individualmente en sólo el 9\%. Cuando se evaluó en conjunto, este porcentaje aumenta a 42\%, lo que indica que, en conjunto - IMC y la insatisfacción - agregan mayor valor explicativo a esta variación. La insatisfacción se consideró la variable más relevante, influido en los valores de estimación en proporciones mayores, sobre todo entre las mujeres de peso normal.

Palabras clave: Imagen corporal; Estimatición; Mujeres; Indice de Massa Corporal; Satisfación. 


\section{Introduction}

The perception that individuals have of their body and the way they interpret them go by subjective components (affective and cognitive). It results in many behaviors, such as patterns of established social relationships, the practice of physical activity and eating behavior (Laus, Straatmann, Kakeshita, Costa Braga, \& Almeida, 2013).

Body image was defined by Gardner (1996) as the "mental picture" that the individual has about the size, contour, and shape of the body, beyond feelings concerning these dimensions. Thus, it is possible to distinguish two components of body image: perceptual and attitudinal. The perceptual component of body image can be defined as the individual's accuracy in judging the size, shape and weight of his/her physical proportions so that the under or overestimation are addressed as perceptual body image disorders (Gardner, 2012). The attitudinal component, in turn, is composed of four dimensions: affective, cognitive, behavioral and satisfaction/dissatisfaction, being global or specific to any area of the body (Thompson, Burke, \& Krawczyk, 2012).

Nowadays, body image problems are associated with damages to physical and psychological health, especially in Brazil, where overweight and obesity rates are high as well as eating disorders and cosmetic surgeries (Brasil, 2013; Goldenberg, 2010). The overestimation of body image is prevalent in different populations and is not specifically in individuals with eating disorders. Similarly, dissatisfaction with one's body becomes a constant in Western culture, where the ideal female body is extremely thin and unattainable by most women. These body image disturbances are closely related to various damages of women's health, which are represented by behaviors such as usage of laxatives and diuretics, a practice of restrictive diets and excessive practice of exercises (Cash, 2011).

Specifically regarding overweight and obese conditions, women present emotional factors that are interpreted as causing or consequences of its physical condition (Vasques, Martins, \& Azevedo, 2004). Depression and anxiety symptoms are the most common, particularly among younger women (Van Der Merwe, 2007). According to Silva et al. (2006), these symptoms may result from body image disturbances (e.g. body dissatisfaction), depreciation of self-concept and low self-esteem. Moreover, the reduction of individual well-being and the social avoidance could prejudice the relationships that in turn can initiate depressive symptoms and adverse psychological outcomes.
Generally, the desire to lose weight among overweight individuals refers to the care with physical health, which is stimulated by public health policies aimed at reducing the overweight and obesity rates to prevent cardiovascular diseases and diabetes. However, this desire for a thinner body is also closely associated with the obesity stigmatization, in which the scope of the thin body would lead to beauty, achievement of positive attributes as success and prestige, and social acceptance (Atlantis \& Baker, 2008; Neumark-Sztainer, 2011). In this context, weight stigmatization has been associated with lower self-esteem, higher body dissatisfaction, and poorer psychological functioning, including greater food intake, particularly among obese women (Kakeshita et al., 2013; Shentow-Bewsh, Keating, \& Mills, 2016). These associations are confirmed because overweight individuals that seek professional help for weight reduction also have negative psychological variables as depressive symptoms, low self-esteem and body image dissatisfaction, that follow their perception of their overweight or obesity, besides the possible impairment of the physical health (Gruszka et al., 2011).

On the other hand, the internalization of the thin appearance ideal leads to body image dissatisfaction among most of the women even those with normal weight (Fitzsimmons-Craft et al., 2012). It seems to influence directly how women perceive their bodies, regardless of the overweight or obesity condition (Laus et al., 2013; Murnen, 2011). Women who overestimate their weight are more dissatisfied with their bodies and are more likely to present health risk behaviors such as the unnecessary practice of diets and binge eating episodes (Kuchler \& Variyam, 2003).

Among the overweight population, adult women correspond to the main group that seeks treatments for weight loss; however, most studies in this population have focused on attitudinal aspects of body image (Atlantis \& Baker, 2008; Latner, 2012). Moreover, about non-clinical population, body image publications mostly involve adolescents or undergraduate students (Grogan, 2011; Laus et al., 2014). Few investigations have been conducted among adult women, especially regarding the perceptual evaluation in the Brazilian population.

It is also believed that the inaccuracy of body image estimation is associated with negative psychological outcomes, such as body image dissatisfaction, depressive and anxiety symptoms, low self-esteem and eating disorders (Gaskin et al., 2013; Harring et al., 2010; Johnstone et al., 2008; Roberts \& Duong, 2013). Therefore, it is the perception of being overweight and not the obesity condition that is most associated with psychological distress (Roberts \& Duong, 2013). Thus, 
the body size estimation may have direct consequences on individual physical and mental health, which can influence the body weight achieved or maintained and the behavioral strategies adopted to achieve it (Khambalia et al., 2012; Linder et al., 2010). Thus, the evaluation of the body size estimation predictors may contribute to a better understanding of the way individuals with different nutritional status perceive their body size.

Consequently, this study aimed to quantify the accuracy of body size estimation among normal and overweight women (classified as overweight or obesity) and to evaluate the variables that influence the body image perception (Body Mass Index - BMI, body image dissatisfaction and depressive symptoms), by regression analysis.

\section{Method}

The sample of this study was composed of 80 female adults, aged between 20 and 50 years old. Half of them $(50 \%, \mathrm{n}=40)$ were the Normal weight group, and the other half $(50 \%, n=40)$ was the Overweight group, which was composed of overweight or obese women, according to BMI classification proposed by the World Health Organization (WHO, 2006). The recruitment criteria excluded women with BMI less than $18.5 \mathrm{~kg} / \mathrm{m}^{2}$, as well as women who had any apparent physical disability or pregnancy. Thus, the following inclusion criteria were adopted: to be within the age range previously determined; to have Brazilian nationality; to have completed primary education. The women were invited by the researcher to participate voluntarily in the study and were not given any incentive or material/ financial compensation. Normal-weight participants were recruited on the premises of the USP campus in Ribeirão Preto, whereas those with excess weight were recruited from the USP Nutritional Reeducation Program (PRAUSP), excluding undergraduate students for both groups. Data collection was carried out between the second semester of 2012 and the first half of 2013.

The body image assessment was conducted by the Brazilian Figure Rating Scale (FRS). This instrument was developed for the Brazilian population by Kakeshita, Silva, Zanatta e Almeida (2009) and it has satisfactory psychometric properties: criterion validity index greater than 0.79 ; content validity indicated by the correct ordering of the figures about $83.44 \%$ by the experts consulted and reliability coefficients by test retest above 0.84 . Consists of 15 silhouettes of each sex, presented on individual cards, with progressive changes in measurement scale, with the thinner figure $\left(\mathrm{BMI}=12.5 \mathrm{~kg} / \mathrm{m}^{2}\right)$ to the wider $\left(\mathrm{BMI}=47.5 \mathrm{~kg} / \mathrm{m}^{2}\right)$, considering even the waist-hip ratio. The participants are instructed to choose a card from the arranged ones in ascending order, with the silhouette that most closely matches their body images ("Current" BMI). Afterward, the subjects must indicate the card with the silhouette that they would like to have ("Desire" BMI).

Corresponding BMI to the chosen figures are considered for tabulation and data analysis, which are compared to actual BMI, objectively measured in data collection. The value of the body image estimation is obtained by the operation "Current" BMI - "Real" BMI, in which results near zero indicate an accurate perception of self-image, negative results indicate an underestimation of body size and positive results indicate overestimation. The index of the subjects' dissatisfaction in relation to their body as a whole is provided by the operation "Desire" BMI - "Current" BMI, in which zero results are indicators of overall satisfaction with body image and positive or negative results indicate some degree of dissatisfaction, with a desire of a higher or lower silhouette, respectively.

The measurement of depressive symptoms was conducted by applying the BDI (Beck Depression Inventory) in its Brazilian version (Cunha, 2001). It is an instrument of self-report that consists of 21 questions designed to assess the intensity of depression symptoms. Symptoms of depression are estimated according to four levels: minimal, mild, moderate and intense, for each item. The intensity of symptoms is analyzed by total score, which is obtained by adding up the scores of the items. It is particularly adequate for using with psychiatric patients, but it has been broadly used in general population samples. The internal consistency of the BDI Portuguese version is satisfactory ( 0.81 for students and 0.88 for depressed patients) and similar to other international samples (Gorenstein \& Andrade, 1996). Its factorial structure was tested by Gandini, Martins, Ribeiro e Santos (2007) among women with cancer. A one-factor solution with 13 items with satisfactory reliability $(0.86)$ was obtained.

The Criterion of Economic Classification Brazil (CCEB) is a reliable instrument of economic segmentation developed by the Brazilian Association of Research Companies (ABEP). This system emphasizes its function to estimate the purchasing power of people and urban families, which divides them into economic classes in higher (A) to lower (E) purchasing power. In the present study, we used the version of CCEB from 01/10/2012 (ABEP, 2012), based on 2010 survey data. The economic classes are determined by adding the scores of items, based on the presence and quantity of household items, in the education level of household head and the presence of a domestic worker. 
This project was approved by the Ethics Committee in Research of the Faculty of Philosophy, Sciences, and Letters of Ribeirão Preto, University of São Paulo (CAAE Process: 00841112.5.0000.5407). Participants were invited to participate in the survey receiving researcher guidelines as the nature and objectives of the work, as well as the confidentiality of the responses. Furthermore, they were informed that they could give up participating at the time they judged necessary, without any harm. The participants who consented to participate in the study signed an informed consent.

Initially, were collected socio-demographic data such as age, marital status, and education, followed by the application of the CCEB by the researcher and the BDI. Then, the FRS was applied for evaluation of the current and desired silhouettes of each participant. Finally, measurements of weight and height of the participants were collected by the main researcher. This procedure was performed at the end of data collection, just to avoid bias in the participant's responses in the body image assessment.

Statistic analyses were conducted using SPSS software, version 16.0. First, descriptive analyses, with values of mean, standard deviation, and ranges of variation percentages were performed. Comparisons of mean scores of normal and overweight groups were made with the Student $t$ test. The associations between variables were also explored by models of simple and multiple linear regression, entering the independent variables BMI, BDI, and dissatisfaction, individually and together concerning the dependent variable: the body image estimation. In setting these models, the coefficient of determination $\left(\mathrm{R}^{2}\right)$ indicates an estimated value of the proportion of the variability of the estimation that is explained by the set of variables. In all analyses were adopted a significant level of 5\%.

\section{Results}

The average age of normal weight women was $35.6(\mathrm{DP}=6.93)$ years old. Most of these women were single $(47.50 \% ; \mathrm{n}=19)$ and had no children $(55 \%$; $\mathrm{n}=22)$. Most of them had completed graduation degree $(82.50 \% ; n=33)$ while the others had completed high school, and $55 \%(\mathrm{n}=22)$ of them belong to economy class B, according to the CCEB. Already Overweight group had a mean age of $35.85(\mathrm{DP}=9.16)$ years old. Most women in this group were married $(60 \% ; n=24)$ and had children $(60 \% ; n=24)$. More than half of these women had completed graduation degree $(55 \% ; n=22)$, most of them also had completed high school (40\%; $n=16)$, and $75 \%(n=30)$ of them belong to economy class $\mathrm{B}$, according to the CCEB.
No statistically significant differences were found between groups for mean age $\left(\mathrm{Diff}=0.25 ; t_{78}=-0.14\right.$; $\mathrm{p}>0.05$ ) or CCEB scores (Diff $=1.52 ; t_{78}=1.19$; $p>0.05)$. The observed frequencies for each of these ratings were similar between groups, not being verified significant effect for variables: marital status $\left(\chi^{2}=3.15 ; \mathrm{df}=3, \mathrm{p}>0.05\right)$, children $\left(\chi^{2}=1.81 ; \mathrm{df}=1\right.$; $\mathrm{p}>0.05)$ and economy class $\left(\chi^{2}=5.03 ; \mathrm{df}=5, \mathrm{p}>0.05\right)$. However, differences were found between groups for the education variable $\left(\chi^{2}=7.72 ; \mathrm{df}=2, \mathrm{p}<0.05\right)$. The socio-demographic data are shown in Tables 1 below.

TABLE 1

Absolute and relative frequencies of qualitative and socio demographic variables of women of normal weight $(n=40)$ and overweight $(n=40)$ groups.

\begin{tabular}{|c|c|c|c|c|c|c|}
\hline \multirow[t]{2}{*}{ Variable } & \multicolumn{2}{|c|}{$\begin{array}{c}\text { Normal } \\
\text { weight } \\
(n=40)\end{array}$} & \multicolumn{2}{|c|}{$\begin{array}{c}\text { Overweight } \\
\quad(n=40)\end{array}$} & \multicolumn{2}{|c|}{ Difference } \\
\hline & $N$ & $\%$ & $N$ & $\%$ & $\chi^{2}$ & $p$ \\
\hline \multicolumn{7}{|l|}{ Marital status } \\
\hline Single & 19 & 47.50 & 14 & 35.00 & \multirow{4}{*}{3.15} & \multirow{4}{*}{0.37} \\
\hline Married & 17 & 42.50 & 24 & 60.00 & & \\
\hline Divorced & 3 & 7.50 & 2 & 5.00 & & \\
\hline Widow & 1 & 2.50 & 0 & 0.00 & & \\
\hline \multicolumn{7}{|l|}{ Children } \\
\hline Yes & 18 & 45.00 & 24 & 60.00 & \multirow[t]{2}{*}{1.81} & \multirow[t]{2}{*}{0.18} \\
\hline No & 22 & 55.00 & 16 & 40.00 & & \\
\hline \multicolumn{7}{|l|}{ Education } \\
\hline Graduation & 33 & 82.50 & 22 & 55.00 & \multirow{3}{*}{7.72} & \multirow{3}{*}{0.02} \\
\hline High School & 7 & 17.50 & 16 & 40.00 & & \\
\hline Elementary School & 0 & 0.00 & 2 & 5.00 & & \\
\hline \multicolumn{7}{|l|}{ CEEB Class } \\
\hline A1 & 2 & 5.00 & 1 & 2.50 & \multirow{6}{*}{5.03} & \multirow{6}{*}{0.41} \\
\hline A2 & 11 & 27.50 & 5 & 12.50 & & \\
\hline B1 & 16 & 40.00 & 20 & 50.00 & & \\
\hline B2 & 6 & 15.00 & 10 & 25.00 & & \\
\hline $\mathrm{C} 1$ & 4 & 10.00 & 4 & 10.00 & & \\
\hline $\mathrm{C} 2$ & 1 & 2.50 & 0 & 0.00 & & \\
\hline
\end{tabular}

As already expected, the BMI of the Overweight group was higher than that of the Normal weight group (Diff $\left.=8.29, t_{78}=-10.99, \mathrm{p}<0.05\right)$. In both groups the mean values of estimation $\left(\mathrm{kg} / \mathrm{m}^{2}\right)$ were positive, indicating an overestimation of body image, but there was no statistically significant difference between them (Diff $\left.=0.63, t_{78}=-0.79, \mathrm{p}>0.05\right)$. The dissatisfaction and depression symptoms were significantly more pronounced in the Overweight group (Dissatisfaction: Diff $=5.25, t_{78}=5.86, \mathrm{p}<0.05 ; \quad$ BDI: Diff $=5.00$, $\left.t_{78}=-2.82, \mathrm{p}<0.05\right)$. A complete description of these variables is shown in Table 2 . 
TABLE 2

Descriptive anthropometric characteristics of the sample, by group $(n=80)$.

\begin{tabular}{|c|c|c|c|c|c|c|c|}
\hline \multirow[b]{2}{*}{ Variable } & \multirow[b]{2}{*}{$\begin{array}{l}\text { Normal weight } \\
\quad(n=40)\end{array}$} & \multirow[b]{2}{*}{$\begin{array}{l}\text { Overweight } \\
\quad(n=40)\end{array}$} & \multicolumn{5}{|c|}{ Difference } \\
\hline & & & Diff. & $F$ & $t$ & $p$ & $\begin{array}{c}d \\
(C I 95 \%)\end{array}$ \\
\hline \multicolumn{8}{|l|}{ Age (years) } \\
\hline Mean (SD) & $35.60(6.93)$ & $35.85(9.16)$ & \multirow{3}{*}{0.25} & \multirow{3}{*}{6.14} & \multirow{3}{*}{$-0.140,34$} & \multirow{3}{*}{0.89} & \multirow{3}{*}{$\begin{array}{c}0.03 \\
(-3.87 ; 3.37)\end{array}$} \\
\hline Median (ITQ) & $34.00(10.75)$ & $35.00(18.50)$ & & & & & \\
\hline Min. - Max. & $22.00-50.00$ & $21.00-50.00$ & & & & & \\
\hline \multicolumn{8}{|l|}{ CCEB (score) } \\
\hline Mean (SD) & $31.27(6.52)$ & $29.75(4.83)$ & \multirow{3}{*}{1.52} & \multirow{3}{*}{2.30} & \multirow{3}{*}{1.19} & \multirow{3}{*}{0.24} & \multirow{3}{*}{$\begin{array}{c}0.24 \\
(-1.03 ; 4.08)\end{array}$} \\
\hline Median (ITQ) & $32(7.75)$ & $30(5.50)$ & & & & & \\
\hline Min. - Max. & $17-45$ & $18-42$ & & & & & \\
\hline \multicolumn{8}{|l|}{ Weight (kg) } \\
\hline Mean (SD) & 59.77 (5.09) & $80.41(13.70)$ & \multirow{3}{*}{20.63} & \multirow{3}{*}{11.62} & \multirow{3}{*}{-8.92} & \multirow{3}{*}{0.00} & \multirow{3}{*}{$\begin{array}{c}2.22 \\
(-25.27 ;-15.99)\end{array}$} \\
\hline Median (ITQ) & $59.97(7.21)$ & $78.50(13.71)$ & & & & & \\
\hline Min. - Max & $50.60-69.25$ & $59.30-122.60$ & & & & & \\
\hline \multicolumn{8}{|l|}{ Height (m) } \\
\hline Mean (SD) & $1.64(0.04)$ & $1.62(0.07)$ & \multirow{3}{*}{0.02} & \multirow{3}{*}{7.15} & \multirow{3}{*}{1.41} & \multirow{3}{*}{0.16} & \multirow{3}{*}{$\begin{array}{c}0.40 \\
(-0.01 ; 0.04)\end{array}$} \\
\hline Mediana (ITQ) & $1.64(0.07)$ & $1.63(0.10)$ & & & & & \\
\hline Min. - Max & $1.55-1.73$ & $1.50-1.81$ & & & & & \\
\hline BMI $\left(\mathrm{kg} / \mathrm{m}^{2}\right)$ & & & & & & & \\
\hline Mean (SD) & $22.15(1.64)$ & $30.44(4.48)$ & 8 20 & 20,87 & 1000 & $0 \Omega 0$ & 2.73 \\
\hline Median (ITQ) & $22.11(2.24)$ & $29.27(4.95)$ & & & 10.8 & & $(-9.81 ;-6.77)$ \\
\hline Min. - Max & $18.50-24.86$ & $25.09-41.88$ & & & & & \\
\hline Estimation $\left(\mathrm{kg} / \mathrm{m}^{2}\right.$ & & & & & & & \\
\hline Mean (SD) & $5.71(3.40)$ & $6.34(3.76)$ & 063 & 027 & 79 & 043 & 0.20 \\
\hline Median (ITQ) & $5.84(4.25)$ & $5.84(5.03)$ & & & & & $(-2.23 ; 0.96)$ \\
\hline Min. - Max & $-2.09-13.31$ & $0.00-16.01$ & & & & & \\
\hline Dissatisfaction (kg & & & & & & & \\
\hline Mean (SD) & $-4.00(4.27)$ & $-9.25(3.72)$ & 5.25 & 0.26 & 586 & 000 & 1.47 \\
\hline Median (ITQ) & $-5.00(6.87)$ & $-7.50(5.00)$ & & & & 0.00 & $(3.47 ; 7,03)$ \\
\hline Min. - Max & $-15.00-2.50$ & $-17.50--2.50$ & & & & & \\
\hline BDI (score) & & & & & & & \\
\hline Mean (SD) & $8.65(7.75)$ & $13.65(8.09)$ & 500 & $0 \Omega 6$ & 282 & 001 & 0.71 \\
\hline Median (ITQ) & $6.50(7.00)$ & $13.00(7.75)$ & & & & 0.01 & $(-8.53 ;-1.47)$ \\
\hline Min. - Max & $0.00-37.00$ & $0.00-36.00$ & & & & & \\
\hline
\end{tabular}

The simple regression analyses were conducted to identify the main predictors (BMI, BDI score, and dissatisfaction) of body size estimation. These results are presented in Table 3. Regarding Normal weight group $(n=40)$, the estimation values were correlated with all variables: $\mathrm{BMI}(\mathrm{t}=2.92, \mathrm{p}=0.01)$ dissatisfaction $(\mathrm{t}=-7.00, \mathrm{p}=0.01)$, and BDI score $(\mathrm{t}=2.51, \mathrm{p}=0.02)$. The coefficient for the dissatisfaction variable was negative which indicates that the lower the rate of dissatisfaction (more dissatisfaction), the higher the body size estimation tends to be. The inverse relationship was observed between BMI and depression symptoms (BDI), indicating that the increase of these variables is followed by increased rates of estimation. However, body image dissatisfaction was the main predictor of body size estimation explain $55 \%$ of its 
variance (adjusted $\mathrm{R}^{2}=0.55$ ). It means that the higher body image dissatisfaction increases the possibility to be inaccurate in estimating the body size.

In relation to the Overweight group $(n=40)$, only BMI $(\mathrm{t}=-2.16, \mathrm{p}=0.04)$ and dissatisfaction $(\mathrm{t}=-2.72$, $\mathrm{p}=0.01)$ were correlated to estimation indices. The coefficients of these variables were both negative, indicating that the lower the rate of dissatisfaction (more dissatisfaction) and the lower BMI, the greater the body size estimation tends to be. Body image dissatisfaction was also the main predictor of body size estimation, but it can explain only $14 \%$ of its variance (adjusted $\mathrm{R}^{2}=0.14$ ).

Thus, we proceeded to the multiple linear regression analyzes to verify the prediction of these three variables together in the body size estimation. These results are presented in Table 4. Regarding Normal weight group $(n=40)$, the model with three independent variables (BMI, dissatisfaction, and BDI) were not significant $(p>0.05)$. The multiple regression models that include dissatisfaction have greater adjusted determination coefficients (BMI and dissatisfaction: adjusted $\mathrm{R}^{2}=0.54$; dissatisfaction and BDI: adjusted $\mathrm{R}^{2}=0.55$; $\mathrm{BMI}$, dissatisfaction and $\mathrm{BDI}$ : adjusted $\mathrm{R}^{2}=0.54$ ). These values are similar to that obtained by the simple linear regression (dissatisfaction: adjusted $\mathrm{R}^{2}=0.55$ ). It means that dissatisfaction is the independent variable that better predicts the body size estimation among normalweight women.

TABLE 3

Simple linear regression analysis between BMI, BDI score and dissatisfaction regarding the estimation, in the total sample $(\mathrm{n}=80)$.

\begin{tabular}{llccccccc}
\hline \multicolumn{1}{c}{ FRS Estimation } & \multicolumn{1}{c}{ Variables } & $R$ & $R^{2}$ & $R^{2}$ Adjusted & $F$ & Constant & $t$ & $P$ \\
\hline Normal weight & BMI & 0.43 & 0.18 & 0.16 & 8.54 & -13.95 & 2.92 & 0.01 \\
& Dissatisfaction & 0.75 & 0.56 & 0.55 & 49.04 & 3.32 & -7.00 & 0.00 \\
& BDI & 0.38 & 0.14 & 0.12 & 6.30 & 4.28 & 2.51 & 0.02 \\
Overweight & BMI & 0.33 & 0.11 & 0.09 & 4.65 & 14.78 & -2.16 & 0.04 \\
& Dissatisfaction & 0.40 & 0.16 & 0.14 & 7.39 & 2.56 & -2.72 & 0.01 \\
& BDI & 0.17 & 0.03 & 0.01 & 1.08 & 5.28 & 1.04 & 0.30 \\
\hline
\end{tabular}

TABLE 4

Multiple linear regression between BMI, BDI score and dissatisfaction regarding the estimation, in the total sample ( $\mathrm{n}=80)$.

\begin{tabular}{|c|c|c|c|c|c|c|c|c|c|}
\hline FRSEstimation & Variables & $R$ & $R^{2}$ & $R^{2}$ Adjusted & $F$ & Constant & $B$ & $t$ & $P$ \\
\hline \multicolumn{10}{|l|}{ Group } \\
\hline \multirow[t]{9}{*}{ Normal weight } & BMI & \multirow[b]{2}{*}{0.75} & \multirow[b]{2}{*}{0.56} & \multirow[b]{2}{*}{0.54} & \multirow[b]{2}{*}{23.94} & \multirow[b]{2}{*}{1.95} & 0.03 & 0.24 & 0.81 \\
\hline & $\begin{array}{l}\text { Dissatisfaction } \\
\text { Dis }\end{array}$ & & & & & & -0.73 & -5.68 & 0.00 \\
\hline & BMI & \multirow{2}{*}{0.56} & \multirow{2}{*}{0.32} & \multirow{2}{*}{0.28} & \multirow{2}{*}{8.62} & \multirow{2}{*}{-14.91} & 0.42 & 3.08 & 0.01 \\
\hline & $\stackrel{*}{\mathrm{BDI}}$ & & & & & & 0.37 & 2.70 & 0.01 \\
\hline & Dissatisfaction & \multirow{2}{*}{0.76} & \multirow{2}{*}{0.58} & \multirow{2}{*}{0.55} & \multirow{2}{*}{25.20} & \multirow{2}{*}{2.99} & -0.71 & -6.16 & 0.00 \\
\hline & BDI & & & & & & 0.12 & 1.07 & 0.29 \\
\hline & BMI & \multirow{3}{*}{0.76} & \multirow{3}{*}{0.58} & \multirow{3}{*}{0.54} & \multirow{3}{*}{16.53} & \multirow{3}{*}{0.15} & 0.06 & 0.48 & 0.63 \\
\hline & Dissatisfaction & & & & & & -0.67 & -4.73 & 0.00 \\
\hline & BDI & & & & & & 0.14 & 1.14 & 0.26 \\
\hline \multirow[t]{9}{*}{ Overweight } & BMI & \multirow{2}{*}{0.67} & \multirow{2}{*}{0.45} & \multirow{2}{*}{0.42} & \multirow{2}{*}{15.33} & \multirow{2}{*}{15.39} & -0.59 & -4.43 & 0.00 \\
\hline & Dissatisfaction & & & & & & -0.64 & -4.83 & 0.00 \\
\hline & BMI & \multirow{2}{*}{0.45} & \multirow{2}{*}{0.20} & \multirow{2}{*}{0.16} & \multirow{2}{*}{4.62} & \multirow{2}{*}{15.62} & -0.44 & -2.82 & 0.01 \\
\hline & BDI & & & & & & 0.32 & 2.05 & 0.04 \\
\hline & Dissatisfaction & \multirow{2}{*}{0.41} & & & & & -0.39 & -2.47 & 0.02 \\
\hline & BDI & & 0.10 & 0.12 & 3.00 & 2.29 & 0.05 & 0.32 & 0.75 \\
\hline & BMI & & & & & & -0.65 & -4.81 & 0.00 \\
\hline & Dissatisfaction & 0.70 & 0.49 & 0.45 & 11.61 & 15.91 & -0.60 & -4.55 & 0.00 \\
\hline & BDI & & & & & & 0.21 & 1.65 & 0.11 \\
\hline
\end{tabular}


Regarding the Overweight group $(n=40)$, the model with all the independent variables (BMI, dissatisfaction, and BDI) was not significant $(\mathrm{p}>0.05)$. The model which includes BMI $(\mathrm{t}=-4.43, \mathrm{p}<0.01)$ and dissatisfaction $(\mathrm{t}=-4.83, \mathrm{p}<0.01)$ as independent variables has a high adjusted determination coefficient (adjusted $\mathrm{R}^{2}=0.42$ ). It means that these variables together can explain $42 \%$ of the estimation variance. Therefore, body image dissatisfaction and BMI are together the better predictors of body size estimation among overweight women. So the inclusion of these two variables in the model resulted in a higher explanation of the dependent variable because the simple regression analyses (dissatisfaction: adjusted $\mathrm{R}^{2}=0.14$ ) can explain only $14 \%$ of its variance.

\section{Discussion}

This study aimed to quantify the body image estimation and to analyze the variables that influence the accuracy of the body image estimation. The associations revealed that women who overestimated their body to a greater extent were those who were more dissatisfied with their body size and those who the BMI were near or corresponding to normal weight and low overweight levels.

Body image dissatisfaction has been consistently identified as a variable that influences how individuals perceive their bodies, underscoring the importance of psychological variables in the process of body size estimation (Cornelissen et al., 2013; Gaskin et al., 2013; Johnstone et al., 2008). The increase of the intensity of dissatisfaction and depression symptoms was followed by increased rates of inaccuracy. These results were also obtained in the Normal weight group in an even more powerful way that the dissatisfaction and BDI explain, $55 \%$ and $12 \%$ of the estimation variance, respectively. These associations support the finding that the perception of being overweight, and not the overweight or obesity condition, is associated with psychological distress (Atlantis \& Ball, 2008; Gaskin et al., 2013).

Given the modern dichotomy represented by the ample supply of densely caloric food and the appreciation of thinness (Kakeshita et al., 2013), the achievement and maintenance of a thin shape or a normal weight could be explained by the presence of dissatisfaction with body image (Cash, 2011). Dissatisfaction, in turn, is mediated by the internalization of the ideal beauty that means how the individual believes and tries to fit this ideal (Fitzsimmons-Craft et al., 2012; Nouri et al., 2011). Besides internalization, social comparison is closely associated with negative body image consequences, so individuals begin to evaluate their appearance negatively when compared to the current standard of beauty and they start to believe it lacks the socially desirable attributes (Mills et al., 2012; Myers \& Crowther, 2009).

Thus, the cult of thinness reflects the social standards of beauty, which are vertiginously propagated by the media, becoming sources of desire for women of all ages. Nevertheless, when these standards cannot be achieved, the dissatisfaction generated influences directly the way they perceive their body (Laus et al., 2013). Therefore, it can be independent of the overweight or obesity condition (Laus et al., 2013; Murnen, 2011). Women who overestimate their weight are more dissatisfied with their bodies and are more likely to submit to health risk behaviors, such as the practice of restrict diets and binge eating episodes, use of laxatives and diuretics, in addition to performing excessive exercises (Cash, 2011; Kuchler \& Variyam, 2003). This situation leads to greater weight gain over time, feeding back this cycle (Lynch et al., 2009). In summary, these body image disorders can significantly contribute to impairments in the physical and psychosocial functioning of the individual (Wilson et al., 2013).

Given this context, it becomes increasingly necessary to prepare health promotion strategies that promote positive body image. This purchase is considered a protective factor for the adverse effects of messages and appearance-related media, as well as for the internalization of the ideal thinness of beauty (Halliwell, 2013). In a broader sense, it is of most importance the creation of awareness programs about the damages to physical and mental health, which are associated with trying to achieve the beauty standard. These actions should be encouraged by professionals and researchers in health and communication, promoting the placement of media images with normal weight, giving them positive attributes of health and beauty (Tiggemann, 2002).

Among women with overweight presently assessed, the dissatisfaction with body image accounted for $14 \%$ of the variance of the body size estimation while the BMI individually made in only $9 \%$. When evaluated together, this percentage increased to $42 \%$, indicating that together - BMI and dissatisfaction - aggregate greater explanatory value to the estimation variance. Although individually the BDI score was not related to the estimation, when associated with BMI the set of variables accounted for $16 \%$ of the variation in body size estimation.

In overweight and obese individuals, the relationship between these variables is complex, 
because dissatisfaction and depressive symptoms are closely associated with the stigmatization of obesity, which thereby influences the body size perception. However, regression analyses indicated that women with a BMI close to a low overweight condition overestimated themselves to a greater extent. It reinforces the finding that is the overweight perceived - rather than actual condition - that is associated with suffering psychological, represented in this study by body dissatisfaction and depressive symptoms (Gaskin et al., 2013; Harring et al., 2010; Johnstone et al., 2008; Roberts \& Duong, 2013).

In the context of overweight and obesity, psychological distress is closely associated with the stigmatization of obesity, so that the scope of the thin body would lead to beauty, achievement of positive mental attributes and social acceptance (Atlantis \& Baker, 2008; Neumark-Sztainer, 2011). The stigmatization experiences suffered by these individuals give harm to psychological functioning, with the emergence of depressive symptoms, which accentuate even more without the proper treatment when coping strategies involve increasing food intake and refusal to practice physical exercises (Latner, 2012). Therefore, in addition to compromising the mental health of the overweight or obese individual, that psychological distress may also impair the adoption of healthy behaviors related to weight and physical health, which, in turn, contributes to weight gain, feeding back the cycle (Latner, 2012).

Thus, strategies for promoting weight loss should incorporate the psychosocial component, with a focus on the positive evaluation of the own body, regardless of the current weight of the individual, which leads to reducing the stigma and difficulties faced by individuals with obesity (Atlantis \& Ball, 2008). The body image satisfaction, when followed by an accurate perception of their weight, can be considered a significant predictor of weight loss and maintenance among overweight individuals (Edwards, Pettingell \& Borowsky, 2010).

According to Laus et al. (2014), Brazilian researchers have been concentrating their efforts on the assessment of body image dissatisfaction and disproportions were observed concerning the age of the participants, wherein adolescents and undergraduates were the target population most often evaluated. Therefore, this study is noteworthy since it evaluated the perceptual component of body image and it this sample is composed of adult women but excluding undergraduates. It expands the understanding of different aspects of body image in this population.

However, it is important to highlight some study limitations that can affect findings. The criterion for the sample composition was the convenience so women who were willing to participate voluntarily in the study could present particular concerns about their body image. The small sample size also could also influence the results obtained in the present study. In addition, the overweight group was composed by women with overweight and obesity diagnosis and it is important to evaluate these subgroups separately.

Furthermore, the Overweight group consisted of women who enrolled in a nutritional education program aimed at weight loss. These women have psychological variables related to body image that may differ from the characteristics presented by overweight and obese women who do not seek professional help for weight loss (Gruszka et al., 2011). Another limitation relates to the lack of symptoms of Binge Eating Disorder (BED) in the overweight sample since the presence of this eating disorder or others has not been investigated. There is some evidence that obese women with this disorder show greater disorders in body image compared to obese without BED (Costa et al., 2010; Ivezaj et al., 2010). In addition, other variables as anxiety, self-esteem and other components of body image construct have not been assessed. They are pointed out as important predictors of body size estimation and may be included in future researchers with the same objective (Gaskin et al., 2013; Harring et al., 2010; Roberts \& Duong, 2013).

\section{Conclusion}

Women who overestimated their body to a greater extent were those who were more dissatisfied with their body size and those who the BMI were near or corresponding to normal weight and low overweight levels. The increase in the intensity of dissatisfaction and depression symptoms was followed by increased rates of inaccuracy in body size estimation. These associations indicated that the perception of being overweight, and not the overweight or obesity condition is associated with psychological distress. 


\section{References}

Atlantis, E. \& Ball, K. (2008). Association between weight perception and psychological distress. International Journal of Obesity, 32, 715-721. http://dx.doi.org/10.1038/sj.ijo.0803762

Atlantis, E. \& Baker, M. (2008). Obesity effects on depression: systematic review of epidemiological studies. International Journal of Obesity, 32, 881-891. http://dx.doi.org/10.1038/ijo.2008.54

Cash, T. F. (2011). Cognitive-behavioral perspectives on body image. In: T. F. Cash \& L. Smoak (Eds.). Body image: a handbook of science, practice, and prevention (pp. 39-47). New York: The Guilford.

Cornelissen, P. L., Johns, A., \& Tovey, M. J. (2013). Body size over-estimation in women with anorexia nervosa is not qualitatively different from female controls. Body Imagem, 10, 103-111. http://dx.doi.org/10.1016/j. bodyim.2012.09.003

Costa, R. F., Machado, S. C., \& Cordas, T. A. (2010). Imagem corporal e comportamento sexual de mulheres obesas com e sem transtorno da compulsão alimentar periódica. Revista de Psiquiatria Clínica, 37(1), 27-31. http://dx.doi. org/10.1590/S0101-60832010000100006

Cunha, J. A. (2001). Manual da versão em português das Escalas Beck. São Paulo: Casa do Psicólogo.

Edwards, N. M., Petting ell, S., \& Brodsky, I. W. (2010). Where Perception Meets Reality: Self-Perception of Weight in Overweight Adolescents. Pediatrics, 125, e452-e458. http://dx.doi.org/10.1542/peds.2009-0185

Fitzsimmons-Craft, E. E., Harney, M. B., Koehler, L. G., Danzig, L. E., Riddell, M.K., \& Bar done-Cone, A. M. (2012). Explaining the relation between thin ideal internalization and body dissatisfaction among college women: The roles of social comparison and body surveillance. Body Image, 9(1), 43-49. http://dx.doi.org/10.1016/j.bodyim.2011.09.002

Gardini, R. D. C., Martins, M. D. C. F., Ribeiro, M. D. P., \& Santos, D. T. G. (2007). Inventário de Depressão de Beck-BDI: validação fatorial para mulheres com câncer. PsicoUSF, 12(1), 23-31. http://dx.doi.org/10.1590/S141382712007000100004

Gardner, R. M. (1996). Methodological issues in assessment of the perceptual component of body image disturbance. British Journal of Psychology, 87(2), 327-337. http://dx.doi.org/10.1111/j.2044-8295.1996.tb02593.x

Gardner, R. M. (2012). Measurement of Perceptual Body Image. In: T. F. Cash (Ed.), Encyclopedia of Body Image and Human Appearance (Vol. II, pp. 526-532). San Francisco: Academic Press. http://dx.doi.org/10.1016/B978-0-12384925-0.00083-3

Gaskin, J. L., Pulver, A. J., Branch, K., Kabore, A., James, T., \& Zhang, J. (2013). Perception or reality of body weight: Which matters to the depressive symptoms. Journal of Affective Disorders, 150, 350-355. http://dx.doi.org/10.1016/j. jad.2013.04.017

Goldenberg, M. (2010). The body as capital: Understanding Brazilian culture. Vibrant, 7(1), 220-238.

Gorenstein, C. \& Andrade, L (1996). Validation of a Portuguese version of Beck Depression Inventory and the StateTrait Anxiety Inventory in Brazilian subjects. Brazilian Journal of Medical and Biological Research, 29(4), $453-457$.

Grogan, S. (2011) Body image development in adulthood. In T. Cash \& L. Smolak. Body Image: A handbook of science, practice, and prevention (pp. 93-99). New York: Guilford Press.

Gruszka, W., Olszanecka-Glinianowicz, M., Kocełak, P., Wikarek, T., Dąbrowski, P., Mucha, Z., \& Zahorska-Markiewicz, B. (2011). Body self-perception in subjects beginning a three-month multifaceted group weight loss programme. Archives of Psychiatry and Psychotherapy, 2, 31-35.

Halliwell, E. (2013). The impact of thin idealized media images on body satisfaction: Does body appreciation protect women from negative effects? Body Image, 10(4), 509-514. http://dx.doi.org/10.1016/j.bodyim.2013.07.004

Harring, H. A., Montgomer, K., \& Hardin, J. (2010). Perceptions of Body Weight, Weight Management Strategies, and Depressive Symptoms Among US College Students. Journal of American College Health, 59(1), 43-50. http://dx.doi. org/10.1080/07448481.2010.483705

Ivezaj, V., Saules, K. K., Hoodin, F., Alschuler, K., Angelella, N. E., Collings, A. S., et al. (2010). The relationship between binge eating and weight status on depression, anxiety, and body image among a diverse college sample: A focus on Bi/Multiracial women. Eating Behaviors, 11, 18-24. http://dx.doi.org/10.1016/j.eatbeh.2009.08.003

Johnstone, A. M., Steward, A. D., Benson, P. J., Kalafati, M., Rectenwald, L., \& Horgan, G. (2008). Assessment of body image in obesity using a digital morphing technique. Journal of Human Nutrition and Dietetics, 21, 256-267. http:// dx.doi.org/10.1111/j.1365-277X.2008.00862.x

Kakeshita, I. S., Silva, A. I. P., Zanatta, D. P., \& Almeida, S.S. (2009). Construção e fidedignidade teste-reteste de escalas de silhuetas brasileiras para adultos e crianças. Psicologia: Teoria e Pesquisa, 25(2), 263-270. http://dx.doi. org/10.1590/S0102-37722009000200015

Kakeshita, I. S., Almeida, S. S., \& Laus, M. F. (2013). "Living well but looking good: A modern health dichotomy" A brief overview on women's body image. Motriz, Rio Claro, 19(3), 558-564. http://dx.doi.org/10.1590/S198065742013000300005

Khambalia, A., Hardy, L. L., \& Bauman, A. (2012). Accuracy of weight perception, life-style behaviours and psychological distress among overweight and obese adolescents. Journal of Paediatrics and Child Health, 48, 220-227. http://dx.doi. org/10.1111/j.1440-1754.2011.02258.x

Kuchler, F. \& Variyam, J. N. (2003). Mistakes were made: misperception as a barrier to reducing overweight. International Journal of Obesity, 27, 856-861. http://dx.doi.org/10.1038/sj.ijo.0802293 
Latner, J. D. (2012). Body Weight and Body image in adults. In: T. F. Cash (Ed.), Encyclopedia of Body Image and Human Appearance (Vol. I, pp. 264-269). San Francisco: Academic Press. http://dx.doi.org/10.1016/B978-0-12384925-0.00044-4

Laus, M. F., Straatmann, G., Kakeshita, I. S., Braga Costa, T. M., \& Almeida, S. S. (2013). A influência da imagem corporal no comportamento alimentar. In. S. S. Almeida, T. M. Braga Costa, M. F. Laus, \& G. Straatmann. Psicobiologia do Comportamento Alimentar (pp. 103-118). Rio de Janeiro: Rubio.

Laus, M. F., Kakeshita, I. S., Braga Costa, T. M., Ferreira, M. E. C., Fortes, L. de S., \& Almeida, S. S. (2014). Body image in Brazil: recent advances in the state of knowledge and methodological issues. Revista de Saúde Pública, 48(2), 331-346. http://dx.doi.org/10.1590/S0034-8910.2014048004950

Linder, J., McLaren, L., Siou, J. L., Csizmadi, I., \& Robson, P. J. (2010). The Epidemiology of Weight Perception: Perceived Versus Self-reported Actual Weight Status among Albertan Adults. Canadian Journal of Public Health, 101(1), 56-60.

Lynch, E., Liu, K., Wei, G. S., Spring, B., Kiefe, C., \& Greenland, P. (2009). The Relation Between Body Size Perception and Change in Body Mass Index Over 13 Years. American Journal of Epidemiology, 169(7), 857-866. http://dx.doi. org/10.1093/aje/kwn412

Mills, J. S., Jadd, R., \& Key, B. L. (2012). Wanting a body that's better than average: the effect of manipulated body norms on ideal body size perception. Body Image, 9(3), 365-372. http://dx.doi.org/10.1016/j.bodyim.2012.03.004

Murnen, S. K. (2011) Gender and Body Images. In T. Cash \& L. Smolak. Body Image: A handbook of science, practice, and prevention (pp. 173-179). New York: Guilford Press.

Myers, T. A. \& Crowther, J. H. (2009). Social comparison as a predictor of body dissatisfaction: a meta-analytic review. Journal of Abnormal Psychology, 118(4), 683-698. 9

Neumark-Sztainer, D. (2011). Obesity and body image in youth. In T. Cash \& L. Smolak. Body Image: A handbook of science, practice, and prevention (pp. 180-188). New York: Guilford Press.

Nouri, M., Hill, L. G., \& Orrell-Valente, J. K. (2011). Media exposure, internalization of the thin ideal, and body dissatisfaction: Comparing Asian American and European American college females. Body Image, 8(4), 366-372. http://dx.doi.org/10.1016/j.bodyim.2011.05.008

Roberts, R. E. \& Duong, H. T. (2013). Perceived weight, not obesity, increases risk for major depression among adolescents. Journal of Psychiatric Research, 47, 1110-1117. http://dx.doi.org/10.1016/j.jpsychires.2013.03.019

Shentow-Bewsh, R., Keating, L., \& Mills, J. S. (2016). Effects of anti-obesity messages on women's body image and eating behaviour. Eating behaviors, 20, 48-56. http://dx.doi.org/10.1016/j.eatbeh.2015.11.012

Silva, M. P., Jorge, Z., Domingues, A., Nobre, E. L., Chambel, P., \& Castro, J. J. (2006). Obesidade e qualidade de vida. Acta Médica Portuguesa, 19(3), 247-250.

Tiggemann, M. (2002). Media influences on body image development. In T. F. Cash, \& T. Pruzinsky (Eds.), Body image: A handbook of theory, research, and clinical practice (pp. 91-98). New York: The Guilford Press.

Thompson, J. K., Burke, N. L., \& Krawczyk. (2012). Measurement of Body Image in Adolescence and Adulthood. In T. F. Cash (Ed.), Encyclopedia of Body Image and Human Appearance (Vol. II, pp. 512-520). San Francisco: Academic Press. http://dx.doi.org/10.1016/b978-0-12-384925-0.00081-x

Van Der Merwe, M-T. (2007). Psychological correlates of obesity in women. International Journal of Obesity, 31, S14-S18. http://dx.doi.org/10.1038/sj.ijo.0803731

Vasques, F., Martins, F. C., \& Azevedo, A. P. (2004). Aspectos psiquiátricos do tratamento da obesidade. Revista de Psiquiatria Clínica, 31(4), 195-198. http://dx.doi.org/10.1590/S0101-60832004000400013

Wilson, R. E., Latner, J. D., \& Hayashi, K. (2013). More than just body weight: The role of body image in psychological and physical functioning. Body Image, 10(4), 644-647. http://dx.doi.org/10.1016/j.bodyim.2013.04.007

World Healthy Organization (WHO). (2006). Global Database on Body Mass Index. Reporton WHO Consultation on Obesity. Geneve: WHO.

\footnotetext{
Autores:

Endereço para correspondência:

Sebastião Sousa Almeida

Av. Bandeirantes, 3900

14040-901 Ribeirão Preto, SP, Brazil

<sebasalm@usp.br>
}

Gabriela Salim Xavier - Mestre, Universidade de São Paulo.

Sebastião Sousa Almeida - PhD, Universidade de São Paulo.

Recebido em: 08.10.2015

Aceito em: 30.05 .2016 